\title{
New U-Pb (zircon) age and geochemistry of the Wedgeport pluton, Meguma terrane, Nova Scotia
}

\author{
Natalie J. MacLean, ${ }^{1}$ Sandra M. Barr,${ }^{1 *}$ Chris E. White, ${ }^{2}$ and John W.F. Ketchum ${ }^{3 \dagger}$ \\ 1. Department of Geology, Acadia University, Wolfville, NS B4P 2R6, Canada \\ 2. Nova Scotia Department of Natural Resources, P.O. Box 698, Halifax, NS B3N 2T9, Canada \\ 3. Jack Satterly Geochronology Lab, Royal Ontario Museum, 100 Queen's Park, Toronto, ON M5S 2C6, Canada \\ *Corresponding author <sandra.barr@acadiau.ca> \\ $†$ Current address: GEMOC ARC National Key Centre, Department of Earth and Planetary Sciences, \\ Macquarie University, NSW 2109, Australia
}

Date received: March 22, 2004 g Date accepted:June 29, 2004

\begin{abstract}
A new U-Pb (zircon) age of $357 \pm 1$ Ma for the Wedgeport pluton in the Meguma terrane of southwestern Nova Scotia confirms that it is younger than other granitoid plutons of the Meguma terrane but not as young as the ca. 316 Ma age based on previous geochronological work. The pluton consists of mainly homogeneous biotite monzogranite characterized by abundant accessory phases including garnet, zircon, epidote, titanite, and ilmenite. Major minerals are quartz, plagioclase (albite-oligoclase), and perthitic microcline. The pluton has consistently high $\mathrm{SiO}_{2}$ content (average ca. $75 \%$ ) but shows some internal variation consistent with fractional crystallization of feldspar and biotite, together with accessory phases such as zircon. Tectonic setting during emplacement of the pluton was likely within plate, but classification is ambiguous because the pluton has characteristics of all three granite types. Peraluminous composition and presence of ilmenite and aluminous minerals such as Fe-rich biotite and garnet suggest S-type affinity, but other characteristics such as high-level emplacement, accessory fluorite, and some chemical characteristics (high $\mathrm{Ga} / \mathrm{Al}$ ratio, elevated $\mathrm{Nb}$ and $\mathrm{Y}$ ) indicate A-type affinity, whereas abundant titanite and overall chemical character is compatible with felsic I-type composition. The granite has specialized characteristics such as elevated $\mathrm{Rb}$ relative to $\mathrm{Sr}$ and $\mathrm{Ba}$, and high $\mathrm{U}$ and $\mathrm{Th}$ compared to all of the average granite types. High $\varepsilon_{\mathrm{Nd}}$ values $(+2$ to +3$)$ indicate a relatively primitive source compared to other plutons of the Meguma terrane. The Wedgeport pluton appears to be unique in the Meguma terrane in both age and composition, although similar plutons may occur in inboard terranes of the Appalachian orogen.
\end{abstract}

\section{RÉSUMÉ}

Une nouvelle datation au U-Pb (à partir de zircon) situant à environ $357 \mathrm{Ma}$ le pluton de Wedgeport à l'intérieur du terrane de Meguma dans le Sud-Ouest de la Nouvelle-Écosse, confirme qu'il est plus récent que les autres plutons granitiques du terrane de Meguma, mais qu'il a plus des 316 Ma qu'on lui avait attribués dans le cadre de travaux géochronologiques antérieurs. Le pluton est constitué de monzogranite à biotite principalement homogène caractérisé par des phases accessoires abondantes, notamment du grenat, du zircon, de l'épidote, de la titanite et de l'ilménite. Les principaux minéraux présents sont le quartz, le feldspath plagioclase (albite-oligoclase) et la microcline perthitique. Le pluton a une teneur constamment élevée en $\mathrm{SiO}_{2}$ (en moyenne environ $75 \%$ ), mais il présente une certaine variation interne correspondant à une cristallisation fractionnée des feldspaths et de la biotite, ainsi que des phases accessoires, dont du zircon. L'intrusion du pluton est probablement survenue dans un cadre tectonique intra-plaque, mais sa classification est ambiguë parce que le pluton possède des caractéristiques des trois types de granites. Sa composition hyperalumineuse et la présence d'ilménite et de minéraux alumineux, comme de la biotite riche en fer et du grenat, laissent supposer une affinité de type $S$, mais d'autres caractéristiques, comme l'intrusion de haut niveau, la fluorine accessoire et certaines caractéristiques chimiques (rapport $\mathrm{Ga} / \mathrm{Al}$ élevé, teneur élevée en $\mathrm{Nb}$ et $\mathrm{Y}$ ), témoignent d'une affinité de type $\mathrm{A}$, tandis que l'abondance de titanite et son caractère chimique général sont compatibles avec une composition de type I felsique. Le granite présente des caractéristiques spécialisées, telles qu'une quantité élevée de Rb par rapport au $\mathrm{Sr}$ et au $\mathrm{Ba}$, et des teneurs élevées en $\mathrm{U}$ et en Th comparativement à tous les types de granites moyens. Les valeurs $\varepsilon_{\mathrm{Nd}}$ élevées $(+2$ à +3$)$ signalent une source relativement primitive comparativement aux autres plutons du terrane de Meguma. Le pluton de Wedgeport semble unique à l'intérieur du terrane de Meguma tant du point de vue âge que composition, même si des plutons analogues peuvent être présents dans des terranes intérieurs.

[Traduit par la rédaction.] 


\section{INTRODUCTION}

The Wedgeport pluton in southernmost Nova Scotia differs in both age and composition from the abundant Devonian plutons that characterize the Meguma terrane (Fig. 1). Its specialized characteristics were recognized in the Nova Scotia "granite boom" of the late 1970s and early 1980s, when the poorly exposed pluton was extensively explored and drilled for Sn, W, and U (Cant et al. 1978; Wolfson 1983). Subsequently, the pluton was reported to be significantly younger than the other plutons of the Meguma terrane, with a late Carboniferous U$\mathrm{Pb}$ (zircon) and $\mathrm{Rb}-\mathrm{Sr}$ whole rock age of $316 \pm 5$ and $323 \pm 12$ $\mathrm{Ma}$, respectively (Cormier et al. 1988). This age is similar to some ${ }^{40} \mathrm{Ar} /{ }^{39} \mathrm{Ar}$ ages from mica in plutonic and metasedimentary units and shear zones in the area (e.g., Reynolds et al. 1981, 1987; Dallmeyer and Keppie 1987, 1988; Muecke et al. 1988; Keppie and Dallmeyer 1995; Culshaw and Reynolds 1997). The pluton also yielded younger ${ }^{40} \mathrm{Ar} /{ }^{39} \mathrm{Ar}$ biotite and $\mathrm{Rb}-\mathrm{Sr}$ mineral ages of ca. $257 \mathrm{Ma}$ (Reynolds et al. 1981; Cormier et al. 1988), which, together with the inferred crystallization age, were used to suggest that Permian-Carboniferous plutonism was a significant factor for economic mineralization in the Meguma Terrane (Cormier et al. 1988). It was suggested more recently that emplacement of the Wedgeport pluton may have been linked to extension related to delamination (Keppie and Dallmeyer 1995) or transtension along shear zones as a result of relative motion of the Gondwanan and Laurentian plates (Pe-Piper and Jansa 1999).

The Southwest Nova Mapping Project (White 2003) provided an opportunity to revisit the Wedgeport pluton with detailed mapping and sampling, which was used as the basis for a BSc honours thesis project by the senior author. Furthermore, the previously reported U-Pb (zircon) age was based on a single bulk zircon fraction and thus is not reliable by current standards; hence, the opportunity was also taken to re-date the pluton. The purpose of this paper is to report the results of these studies, together with a compilation of some earlier work on the pluton. The results show that the pluton is older than was indicated by previous dating, but still younger than other granitoid rocks of the Meguma terrane.

\section{GEOLOGICAL SETTING}

The Wedgeport pluton (Taylor 1967) intrudes thickly bedded metasandstone, metasiltstone, and slate of the New Harbour Member, the lower part of the Goldenville Formation (White and King 2002; White 2003) (Figs. 1, 2). The Goldenville Formation is overlain by the mainly pelitic Halifax Formation. In the Yarmouth area west of the Wedgeport pluton (Fig. 1), metavolcanic and metasedimentary rocks of the late Ordovician to Silurian White Rock Formation disconformably overlie or are in faulted contact with the Halifax Formation (MacDonald et al. 2002; White et al. 2001). These units were deformed and metamorphosed during the Acadian orogeny at ca. 395-380 Ma (Hicks et al. 1999), prior to emplacement of the South Mountain Batholith and related plutons at ca. 378$372 \mathrm{Ma}$ (see Clarke et al. 1997 for a summary). The Meguma terrane was juxtaposed with the Avalon terrane to the north by Devonian-Carboniferous dextral transcurrent motion along the Cobequid-Chedabucto fault system (e.g., Keppie 2000). Mantle-derived mafic igneous activity in the Middle Devonian

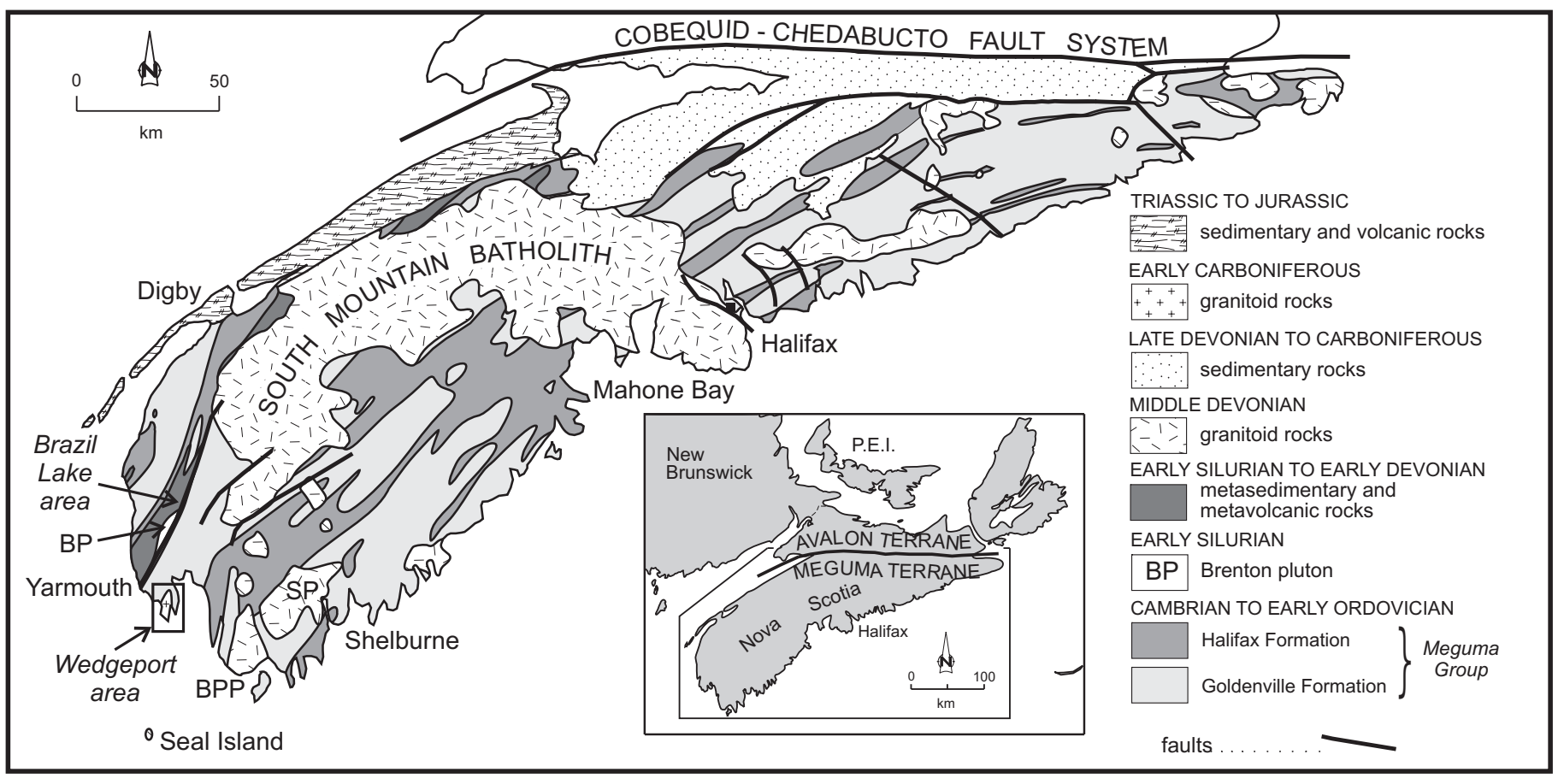

Fig. 1 Geological map of southern Nova Scotia, showing the location of the Wedgeport pluton. Abbreviations: BPP = Barrington Passage Pluton; $\mathrm{BP}=$ Brenton Pluton; $\mathrm{SP}$ = Shelburne Pluton. 
to Carboniferous may have provided the heat source to generate these granitoid magmas by crustal melting (Tate and Clarke 1995). Ongoing localized deformation occurred along shear zones during the Carboniferous (Culshaw and Liesa 1997; Culshaw and Reynolds 1997).

\section{FIELD RELATIONS}

Although the Wedgeport pluton is poorly exposed and outcrop is sporadic, second derivative aeromagnetic data (King 1997a, b, and unpublished data) combined with several drill holes (Cant et al. 1978) clarify the position of the contact in areas of limited or no outcrop. The pluton intruded along the western limb of a north-south-trending, north-plunging anticline (Fig. 2). It produced a narrow (approximately 400 $\mathrm{m}$ wide) contact metamorphic aureole of spotted hornfels containing andalusite and cordierite superimposed on biotite zone assemblages (Cullen 1983). Abundant garnet also was noted during the present study in the more pelitic beds in the metasandstone. The contact metamorphic mineral assemblage is indicative of the albite-epidote to hornblende-hornfels facies, and indicates that the pluton was emplaced at relatively shallow crustal depth, about 3-4 km below surface. The contact zone is well exposed on the western shore of Pinkneys Point (Fig. 2), where the metasedimentary rocks are intruded by granitic dykes from the pluton.

The mainly granitic pluton contains scattered fine- to medium-grained, biotite-rich, round granodioritic enclaves that range in size from a few $10 \mathrm{~s}$ of $\mathrm{cm}$ to $1-2 \mathrm{~m}$ in longest dimension. None of the enclaves were included in the present study. Narrow ( $2-5 \mathrm{~cm}$ wide, rarely $>1 \mathrm{~m})$, pale grey veins and pods of aplite and pegmatite intrude the pluton. Near the margins of the pluton the granite is heterogeneous with textures that range from fine-grained to porphyritic. In addition, igneous layering is present, defined by alternating biotite-rich and feldspar-quartz-rich bands that are broadly parallel to the contact with the adjacent country rocks. Miarolitic cavities are present locally but are generally uncommon (Wolfson 1983). These textural variations suggest that a significant amount of fluid was present during crystallization of the pluton, especially near the margins.

The pluton and adjacent country rock are cut by several thin (1-2 mm to several cm) quartz, quartz-tourmaline, quartz-carbonate, and greisen veins. Typically, the quartz-carbonate and greisen veins contain various sulphide minerals, fluorite, scheelite, white mica, and cassiterite (Wolfson 1983). Northeast- to east-trending shear zones, reported to contain cassiterite, wolframite, molybdenite, and scheelite, cut the pluton, and appear rusty as the result of weathering of associated sulphide minerals, mainly pyrite and arsenopyrite (e.g., Wolfson, 1983). Mylonitic fabrics are common in the shear zones which display well-developed asymmetric quartz augen and C-S fabrics indicating dextral sense of motion (White 2003).

The pluton is cut by lamprophyre and alkaline olivine diabase dykes of early Jurassic age (Cant et al. 1978; Chatterjee and Keppie 1981; Wolfson 1983; Pe-Piper and Reynolds 2000; White and King 2002; White 2003).

\section{PETROGRAPHY}

The Wedgeport pluton is composed mainly of medium- to coarse-grained biotite monzogranite which grades in composition to syenogranite (Fig. 3). Texture is typically hypidiomorphic equigranular and, locally, inequigranular to porphyritic, especially near the margins as described above. Microcline is the dominant feldspar, and simple Carlsbad twins are visible in some grains suggesting that orthoclase was the original form. Perthitic texture is typically present, and albitic lamellae have compositions similar to those of separate plagioclase grains in the rock. Granophyric texture occurs only in samples from the northwestern part of the intrusion; that area may represent the shallowest part at the time of emplacement. Subhedral plagioclase is slightly to extensively altered to saussurite and sericite. Microprobe analyses of plagioclase in 6 samples showed a range in composition from $\mathrm{An}_{1}$ to $\mathrm{An}_{17}$; zoned plagioclase grains do not greatly vary in composition from the core to the rim(MacLean 2003). Anhedral quartz grains commonly show undulatory extinction.

Biotite forms about $15 \%$ of the rock, and typically is partially or wholly altered to chlorite and muscovite. Microprobe analyses (MacLean 2003) revealed that the biotite has a high iron content $(\mathrm{Fe} / \mathrm{Fe}+\mathrm{Mg}=0.73$ to 0.83$)$ and tetrahedral $\mathrm{Al}$ contents of 2 to 2.2 , close to the annite end member. Common inclusions in biotite are titanite, zircon, apatite, ilmenite, epidote, and probably monazite (not easily identified because of small grain size). Titanite is the most abundant accessory mineral in the samples and mainly occurs in association with biotite and ilmenite; the latter mineral is partially or in some cases entirely altered to titanite. Many samples also contain minor amounts of garnet and fluorite. Electron microprobe analyses revealed that the garnet is of almandine-grossular composition with high manganese content (MacLean 2003).

Chatterjee and Keppie (1981) and Chatterjee et al. (1985) divided the Wedgeport pluton into the Goose Bay and Pinkneys Point units, forming the eastern and western parts of the pluton, respectively, with the mutual contact not exposed. They described the Goose Bay granite as garnetiferous, and similar to parts of the South Mountain Batholith. In contrast, the Pinkneys Point granite was described as a more variable unit, containing topaz granite, greisenized granite, albitite, and greisen, and associated with mineralization, including cassiterite, wolframite, scheelite, and a variety of similar lithophileelement minerals (Chatterjee et al. 1985). Chatterjee and Keppie (1981) suggested that the Pinkneys Point pluton may have been the source of fluids that resulted in alteration and mineralized veins in the Wedgeport pluton and adjacent rocks. Observations made during the present study do not provide any evidence to support this subdivision; garnet was observed in samples distributed throughout the pluton, and features ascribed to the Pinkneys Point unit are more likely a reflection 


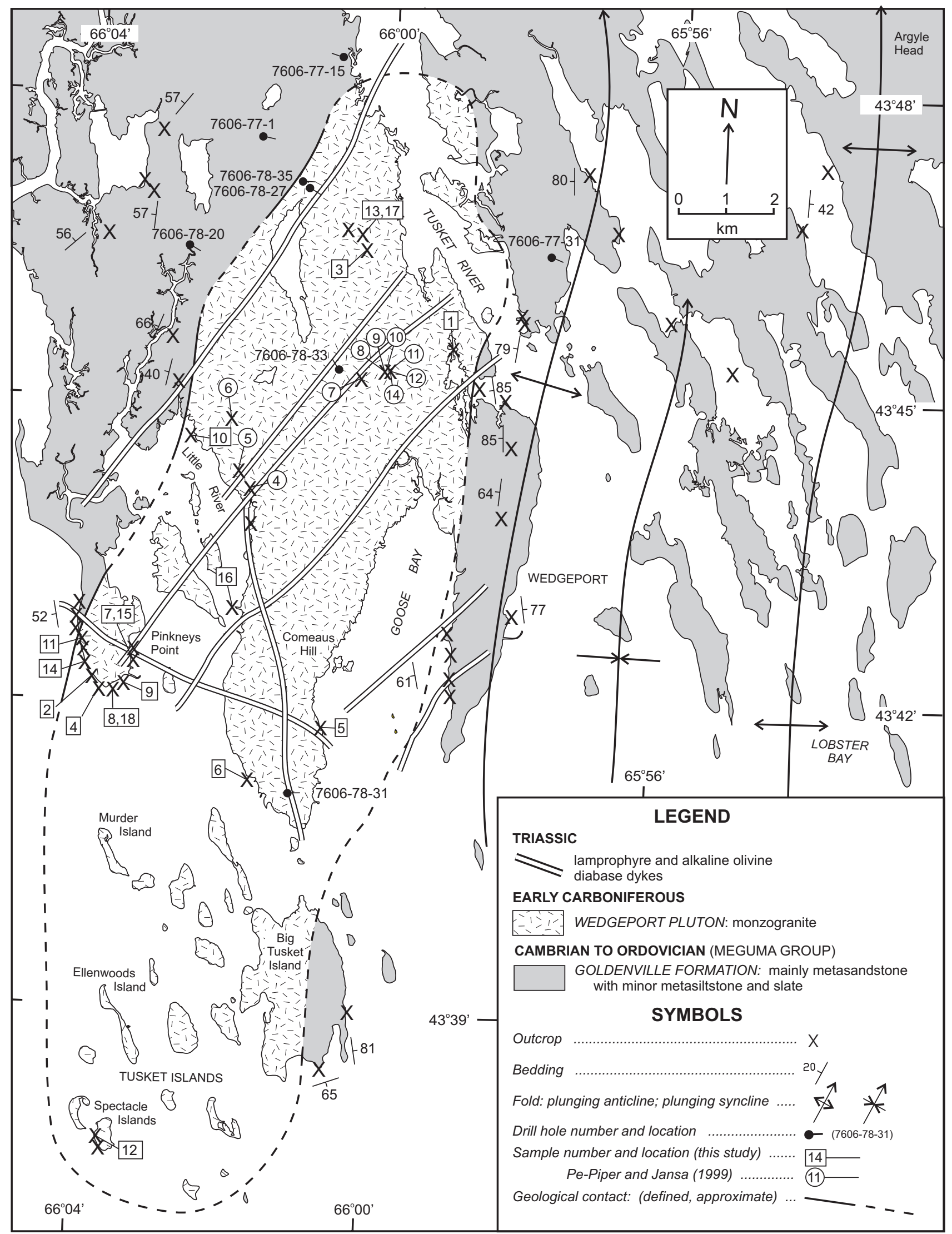

Fig. 2 Geological map of the Wedgeport pluton showing sample locations of the present study and those from Pe-Piper and Jansa (1999). Map is based on White (2003) and the present study. 


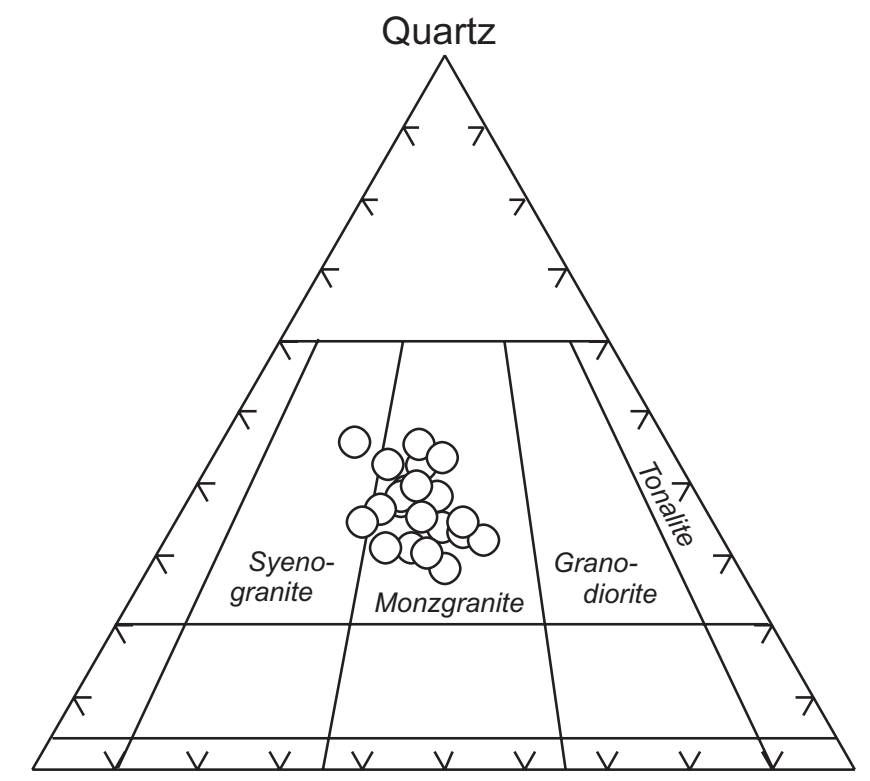

Alkali feldspar

Fig. 3 Modal mineralogy of samples from the Wedgeport pluton plotted on a Q-A-P ternary diagram with fields from Streckeisen (1976).

of the excellent exposure in the Pinkneys Point section and its position near the margin of the pluton.

\section{GEOCHRONOLOGY}

\section{Previous Work}

$\mathrm{U}-\mathrm{Pb}$ and $\mathrm{Rb}-\mathrm{Sr}$ data presented by Cormier et al. (1988) indicated that the Wedgeport pluton crystallized at $316 \pm 5$ $\mathrm{Ma}$, but was reheated at $257 \pm 8 \mathrm{Ma}$ during a thermal event. However, the U-Pb data of Cormier et al. (1988) are difficult to re-assess as no $U$ isotopic information was provided and some aspects of the data are inconsistent between data table and text. Additionally, only one zircon fraction was analyzed, and presumably that fraction was large and multigrain. The zircon was reported to be of poor quality, and it is unlikely that it was air-abraded prior to analysis because at the time of the work, the abrasion technique (Krogh 1982) was not widely used.

$\mathrm{An}{ }^{40} \mathrm{Ar} /{ }^{39} \mathrm{Ar}$ plateau age on biotite at $258 \pm 8$ Ma has also been reported from the Wedgeport pluton (Reynolds et al. 1981); however, this sample showed appreciable alteration of biotite to chlorite (Reynolds et al. 1981). The similarity between the Rb-Sr mineral isochron ages (Cormier et al. 1988) and the ${ }^{40} \mathrm{Ar} /{ }^{39} \mathrm{Ar}$ age from chloritized biotite suggests that both the Rb-Sr and ${ }^{40} \mathrm{Ar} /{ }^{39} \mathrm{Ar}$ systems may record the timing of pervasive alteration in the Wedgeport pluton as opposed to a re-heating event.

Even younger hornblende and biotite ${ }^{40} \mathrm{Ar} /{ }^{39} \mathrm{Ar}$ plateau ages (ca. 231 to $222 \mathrm{Ma}$ and ca. 209 to $203 \mathrm{Ma}$ ) were reported for the lamprophyre and alkaline olivine diabase dykes that

occur in the area (Reynolds et al. 1987; Pe-Piper and Reynolds 2000).

\section{Analytical Methods}

A $20 \mathrm{~kg}$ monzogranite sample was processed at the Royal Ontario Museum in Toronto using standard techniques, including heavy liquids and a Frantz magnetic separator for isolation of heavy mineral fractions. Zircon was selected from the least paramagnetic fraction by hand picking grains under a binocular microscope. All picked zircons were given an air abrasion treatment to eliminate cracked grains and remove exterior surfaces (Krogh 1982). Final selection of grains for analysis was then made. The weight of each fraction (consisting of one to four grains) was determined using an unpublished spreadsheet calculation that estimates fraction weights from photomicrograph measurements of individual zircons. Uncertainties on the estimated weights have not been calculated but are likely to be $<30 \%$ in most cases. This uncertainty only affects the calculation of $\mathrm{Pb}$ and $\mathrm{U}$ concentrations and has no influence on age data.

The selected grains were washed in $4 \mathrm{~N}$ and $7 \mathrm{~N} \mathrm{HNO}_{3}$ and then loaded into Teflon bombs with HF and a measured amount of ${ }^{205} \mathrm{~Pb}-{ }^{235} \mathrm{U}$ isotopic tracer solution (Krogh 1973). Dissolution occurred over four to five days at $195^{\circ} \mathrm{C}$. No chemical isolation of $\mathrm{U}$ and $\mathrm{Pb}$ was carried out on the dissolved grains. Fractions were dried down with phosphoric acid and then loaded with silica gel onto out-gassed rhenium filaments. The isotopic compositions of $\mathrm{Pb}$ and $\mathrm{U}$ were measured using a single Daly collector with a pulse counting detector in a solid source VG354 mass spectrometer. A detector mass discrimination of $0.14 \%$ per atomic mass unit (AMU) and a dead time of $22.5 \mathrm{nsec}$ were employed for Daly detector measurements. A thermal source mass discrimination correction of $0.1 \%$ per atomic mass unit for both $\mathrm{Pb}$ and $\mathrm{U}$ was also used.

Assigned laboratory blank for $\mathrm{U}$ is $0.2 \mathrm{pg}$. Total measured common $\mathrm{Pb}$ in each fraction was below $1 \mathrm{pg}$ in all cases and was assigned the isotopic composition of lab blank (see footnotes to Table 1). Error estimates were calculated by propagating known sources of analytical uncertainty for each analysis including ratio variability (within run), uncertainty in the fractionation correction, and uncertainties in the isotopic composition of laboratory blank. Decay constants used are those of Jaffey et al. (1971). Uncertainties are given at the 95\% confidence level. Discordia lines and concordia intercept ages were calculated by the method of Davis (1982) using the in-house program ROMAGE. The average ${ }^{206} \mathrm{~Pb} / 238 \mathrm{U}$ age reported below was also calculated using ROMAGE.

\section{New Results}

Zircon grains in the Wedgeport granite sample are dominated by euhedral, 4-sided, well-formed igneous prisms ranging from small to large (Fig. 4a, b). Most grains are cracked and/or contain inclusions but the selected grains are free of these 
Table 1. U-Pb isotopic data for Wedgeport pluton sample 016-W02-004A

\begin{tabular}{|c|c|c|c|c|c|c|c|c|c|c|c|c|c|c|c|c|}
\hline \multirow[b]{2}{*}{ Reference } & \multirow[b]{2}{*}{ Fraction $^{(a)}$} & \multirow[b]{2}{*}{$\begin{array}{c}\text { Weight } \\
(\mathrm{mg})\end{array}$} & \multirow[b]{2}{*}{$\begin{array}{c}\mathrm{U} \\
(\mathrm{ppm})\end{array}$} & \multirow[b]{2}{*}{$\frac{\mathrm{Th}^{(\mathrm{b})}}{\mathrm{U}}$} & \multirow[b]{2}{*}{$\begin{array}{c}\text { total } \mathrm{Pb} \\
(\mathrm{pg})\end{array}$} & \multirow[b]{2}{*}{$\begin{array}{l}\text { com. } .^{(\mathrm{c})} \\
\mathrm{Pb}(\mathrm{pg})\end{array}$} & \multicolumn{5}{|c|}{ Ratios } & \multicolumn{4}{|c|}{ Ages $(\mathrm{Ma})$} & \multirow[b]{2}{*}{$\begin{array}{c}\operatorname{disc}^{(\mathrm{d})} \\
(\%)\end{array}$} \\
\hline & & & & & & & $\frac{{ }^{206} \mathrm{~Pb}}{{ }^{204} \mathrm{~Pb}}$ & $\frac{{ }^{206} \mathrm{~Pb}}{{ }^{238} \mathrm{U}}$ & $2 \sigma$ & $\frac{{ }^{207} \mathrm{~Pb}}{{ }^{235} \mathrm{U}}$ & $2 \sigma$ & $\frac{{ }^{206} \mathrm{~Pb}}{{ }^{238} \mathrm{U}}$ & $2 \sigma$ & $\frac{{ }^{207} \mathrm{~Pb}}{{ }^{206} \mathrm{~Pb}}$ & $2 \sigma$ & \\
\hline jk10p16 & Z1 euh clr 2:1 pr (1) & 0.0028 & 265 & 0.53 & 44.8 & 0.2 & 15796 & 0.0575 & 0.0002 & 0.428 & 0.002 & 360.4 & 1.1 & 373.3 & 4.6 & 3.6 \\
\hline jk10p17 & $\mathrm{Z} 2$ euh clr $3: 1 \mathrm{pr}$ incl (3) & 0.0032 & 314 & 0.53 & 59.6 & 0.3 & 13947 & 0.0566 & 0.0002 & 0.421 & 0.001 & 355.0 & 1.1 & 368.1 & 4.9 & 3.7 \\
\hline jk10p18 & Z3 euh clr $3: 1$ pr incl (3) & 0.0030 & 415 & 0.47 & 72.7 & 0.3 & 15268 & 0.0565 & 0.0002 & 0.419 & 0.002 & 354.4 & 1.4 & 363.0 & 4.4 & 2.4 \\
\hline jk10p22 & Z4 eq clr ball (1) & 0.0050 & 308 & 0.42 & 89.3 & 0.5 & 10838 & 0.0570 & 0.0003 & 0.422 & 0.002 & 357.4 & 1.6 & 356.0 & 4.9 & -0.4 \\
\hline jk10p23 & $\mathrm{Z} 5$ euh $2: 1 \mathrm{pr}(4)$ & 0.0028 & 345 & 0.39 & 54.9 & 0.4 & 8044 & 0.0561 & 0.0002 & 0.415 & 0.001 & 351.6 & 1.0 & 358.3 & 4.8 & 1.9 \\
\hline jk10p75 & Z6 clr ball (1) & 0.0045 & 226 & 0.62 & 62.2 & 0.4 & 8911 & 0.0570 & 0.0003 & 0.422 & 0.002 & 357.1 & 1.7 & 362.4 & 5.0 & 1.5 \\
\hline
\end{tabular}

Data are from abraded zircons (Krogh 1982). Decay constants used are those of Jaffey et al. (1971).

Notes: (a) Abbreviations: Z - zircon; euh - euhedral; eq - equant; pr - prism; clr - colourless; incl - inclusions; 2:1, 3:1, etc. - length:breadth ratio; Number in brackets indicates number of grains analysed. (b) Th/ $\mathrm{U}$ - based on radiogenic ${ }^{208} \mathrm{~Pb} /{ }^{206} \mathrm{~Pb}$ ratio and ${ }^{207} \mathrm{~Pb} /{ }^{206} \mathrm{~Pb}$ age. (c) Com. $\mathrm{Pb}=$ total common $\mathrm{Pb}$; blank isotopic composition: ${ }^{206} \mathrm{~Pb} /{ }^{204} \mathrm{~Pb}=18.221,{ }^{207} \mathrm{~Pb} /{ }^{204} \mathrm{~Pb}=15.612,{ }^{208} \mathrm{~Pb} /{ }^{204} \mathrm{~Pb}=39.36$. (d) Disc. = percent discordance for the given ${ }^{207} \mathrm{~Pb} /{ }^{206} \mathrm{~Pb}$ age
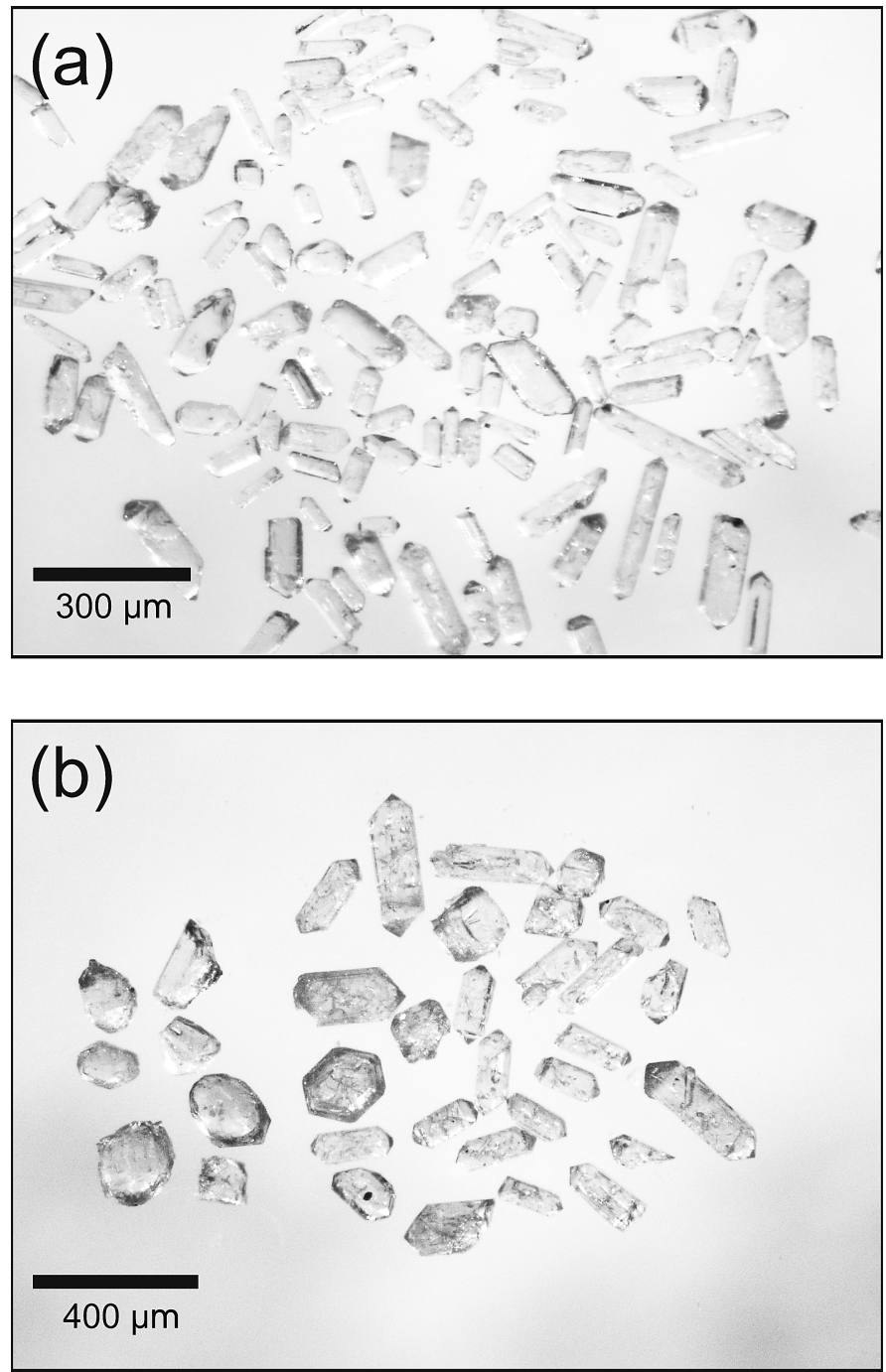

Fig. 4 Photomicrographs of zircon grains from monzogranite sample 016-WO2-004A. (a) small prismatic grains. (b) large prismatic grains.

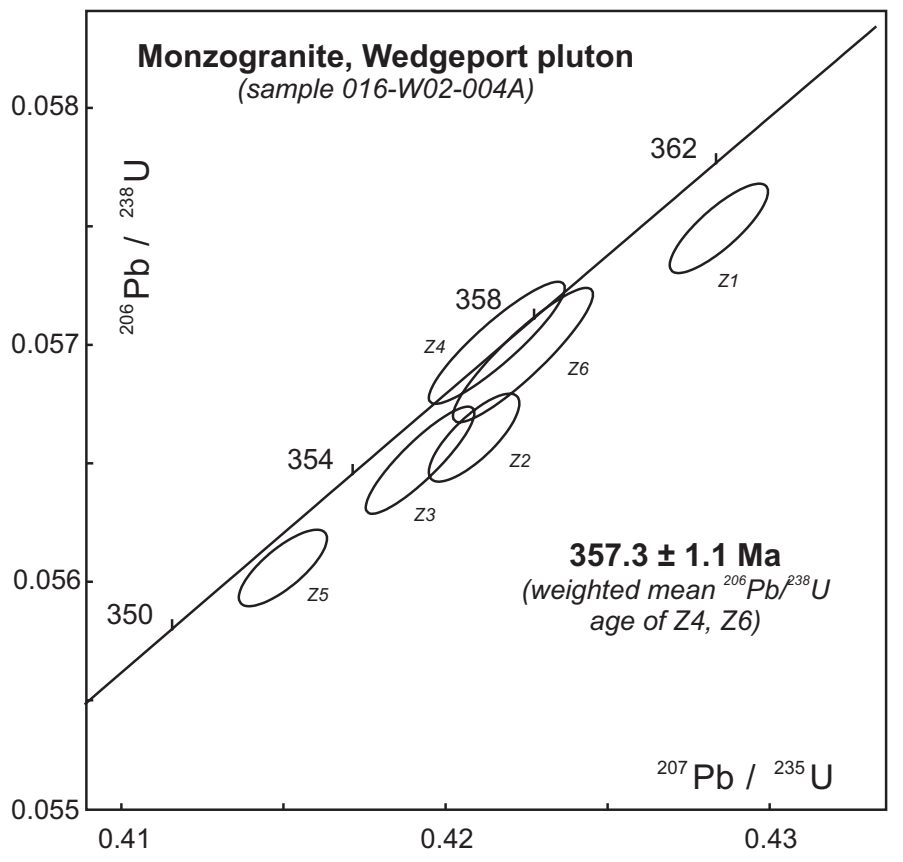

Fig. 5 Concordia diagrams for sample 016-WO2-004A, based on data presented in Table 1. 
features. Six fractions of small and large grains were abraded and analysed separately (Table 1). Fractions Z2, Z3, and Z5 are multigrain fractions of small prisms with inclusions. On the concordia diagram (Fig. 5), these analyses plot distinctly below and to the left of two concordant analyses $(\mathrm{Z} 4, \mathrm{Z6})$ of larger single prisms. Fraction Z1, also a single large grain, is older than all other fractions. Although interpretation of these data is not straightforward, we consider the following scenario to be the most likely. Concordant fractions Z4 and Z6, with identical ${ }^{206} \mathrm{~Pb} /{ }^{238} \mathrm{U}$ ages of $357 \mathrm{Ma}$, are interpreted to give the igneous crystallization age of the granite. The weighted mean ${ }^{206} \mathrm{~Pb} /{ }^{238} \mathrm{U}$ age of these fractions is $357.3 \pm 1.1 \mathrm{Ma}$. Fraction Z5 is interpreted to consist of ca. $357 \mathrm{Ma}$ zircons that experienced some modern-day $\mathrm{Pb}$ loss, and fraction $\mathrm{Z} 1$ appears to contain an inherited component. The age of this component is modelled as $1340+830 /-500 \mathrm{Ma}$, the upper intercept age of a discordia line through fractions $\mathrm{Z1}, \mathrm{Z} 4$, and Z6. The remaining fractions $(\mathrm{Z} 2, \mathrm{Z3})$ have ${ }^{207} \mathrm{~Pb} /{ }^{206} \mathrm{~Pb}$ ages significantly older than $357 \mathrm{Ma}$ and therefore modern-day Pb loss alone cannot account for their discordance. We suggest that $\mathrm{Pb}$ loss combined with the presence of a minor inherited component best explains the discordance of these analyses.

We consider the weighted mean ${ }^{206} \mathrm{~Pb} /{ }^{238} \mathrm{U}$ age of 357.3 $\pm 1.1 \mathrm{Ma}$ to be the best estimate for the crystallization age of the Wedgeport pluton. The previously reported age of $316 \pm 5$ $\mathrm{Ma}$ (Cormier et al. 1988), which was based on a single analysis of highly fractured and metamict grains, may be erroneously young due to significant $\mathrm{Pb}$ loss from these zircons.

\section{GEOCHEMISTRY}

\section{Introduction}

We acquired major and trace element data (Table 2) for 18 samples from surface outcrops of the Wedgeport pluton (Fig. 2). Rare-earth element data were obtained for 5 of these samples (Table 3), and Sm-Nd isotopic data for the dated sample (Table 4). Wolfson (1983) had reported whole-rock analyses of 8 samples from drill core in the Wedgeport pluton, but her data included only a limited suite of trace elements. Pe-Piper and Jansa (1999) also obtained chemical data from 7 samples from the pluton, in order to compare to offshore plutons sampled in drill core. Those data include a suite of trace elements and in two samples, also rare-earth elements, comparable to the present data set, although no petrographic descriptions were provided. Locations for these samples (G. Pe-Piper, written communication, 2004) are shown on Fig. 2. In addition, Chatterjee et al. (1985) presented a large amount of chemical data from the Wedgeport pluton in the form of variation diagrams; however, their focus was on mineralization processes, not petrogenesis and tectonic setting, and the actual chemical data for those samples were not published.

\section{Major and trace elements}

All analyzed samples from the Wedgeport pluton have high silica content (Table 2) that averages about 75\%. Although scattered, most major element oxides show a negative correlation with $\mathrm{SiO}_{2}$ (Fig. 6). Exceptions are $\mathrm{Na}_{2} \mathrm{O}$ and $\mathrm{K}_{2} \mathrm{O}$ (Fig. 6f, g) which show little or no correlation with $\mathrm{SiO}_{2}$. These variations mainly reflect variations in the amount of modal biotite and plagioclase in the analyzed samples. No consistent differences are apparent between samples that contain garnet compared to those that do not, or between the porphyritic sample and the other samples. The two aplite samples do not differ significantly in major element composition from their host rocks. In terms of major element composition, the Wedgeport pluton does not show a clear affinity with any of the average A-type and felsic I- and S-type granites of Whalen et al. (1987). For example, $\mathrm{Na}_{2} \mathrm{O}$ contents are similar to that in the average Itype but lower than in the average A-type and higher than in the average S-type (Fig. 6f), whereas $\mathrm{MgO}$ and $\mathrm{CaO}$ contents are most similar to the average A-type (Fig. $6 \mathrm{~d}, \mathrm{e})$ and $\mathrm{P}_{2} \mathrm{O}_{5}$ content to the average S-type (Fig. 6h).

Trace elements show more diagnostic features (Fig. 7). Both $\mathrm{Ba}$ and $\mathrm{Sr}$ show negative correlation with $\mathrm{SiO}_{2}$, and concentrations below those typical of average felsic I- and S-type granite and most similar to average A-type (Figs. 7a, b). On the other hand, $\mathrm{Rb}$ values show no correlation with $\mathrm{SiO}_{2}$ and are elevated compared to all three granite types (Fig. 7c). This feature is also shown on the $\mathrm{Ba}-\mathrm{Rb}$-Sr ternary diagram (Fig. 8a), in which the samples plot in the area of enriched granite according to El Bouseily and El Sokkary (1975).

The trace elements $\mathrm{Y}, \mathrm{Nb}$, and $\mathrm{Ga}$ show scatter and no consistent correlation with $\mathrm{SiO}_{2}$ (Figs. 7d, e, f), whereas $\mathrm{Zr}$ shows a weak negative correlation (Fig. $7 \mathrm{~g}$ ). The abundances of all of these elements are below those of the average A-type granite, although they tend to be higher than those in the average felsic I- and S-type granites. $V$ show strong negative correlation with $\mathrm{SiO}_{2}$, and higher values than I-, S-, and especially A-type granites (Fig. 7h). Values in the Pe-Piper and Jansa (1999) samples are uniformly lower than those obtained during the present study, most likely due to a systematic analytical problem in one of the data sets. Both $\mathrm{Pb}$ and $\mathrm{Zn}$ show negative correlation with $\mathrm{SiO}_{2}$ (Fig. $\left.7 \mathrm{i}, \mathrm{j}\right)$. Pb tends to be higher in samples that contain garnet, and $\mathrm{Zn}$ values are low compared to the average A-type granite. Concentrations of $\mathrm{Ni}, \mathrm{Cu}$, and $\mathrm{Cr}$ are low and commonly below the detection limit of the analytical method (Table 2), and hence are not displayed graphically.

Th and $U$ values are scattered, but overall higher than those in the average felsic I-, S-, or A-type granites (Fig. 9a, b). A plot of Th against $U$ shows a positive correlation (Fig.9c), and two trends are suggested that correspond to the "unaltered" (lower U) and "altered" (higher U) sample trends identified by Chatterjee et al. (1985). The majority of samples analyzed during the present study, as well as those of Pe-Piper and Jansa (1999), follow the "unaltered" trend.

The Wedgeport pluton is not easily assigned to I-, S-, or A-type on the basis of major or trace element compositions 


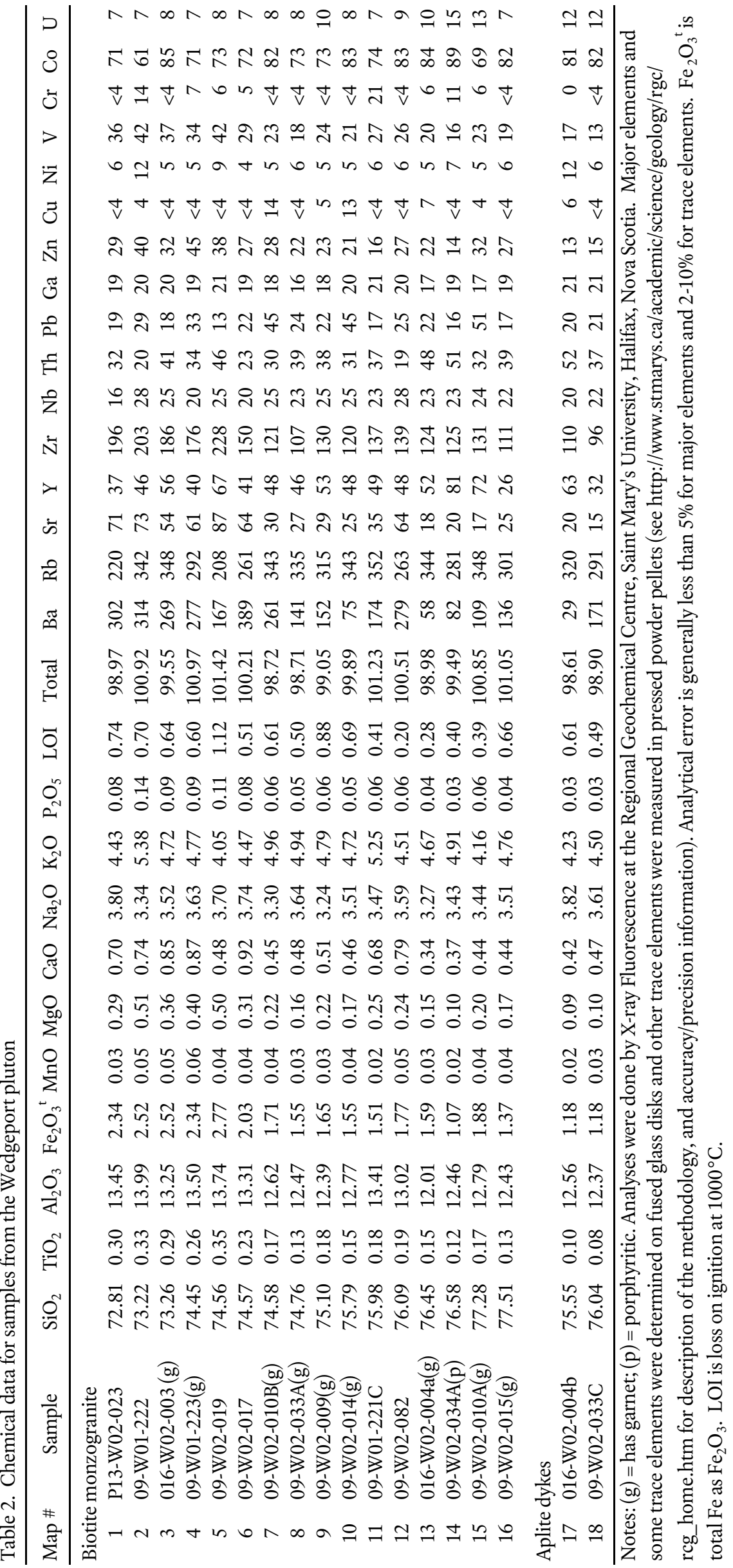

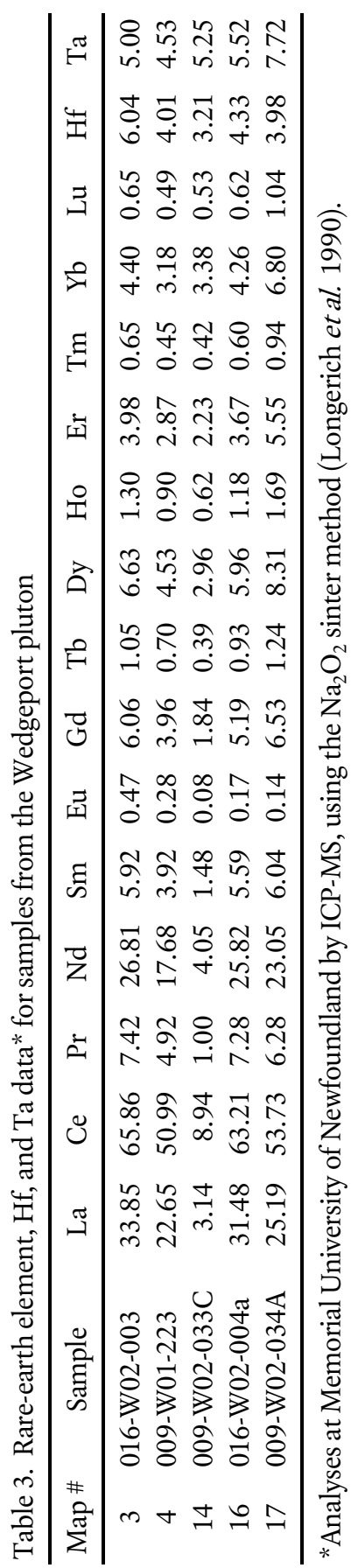



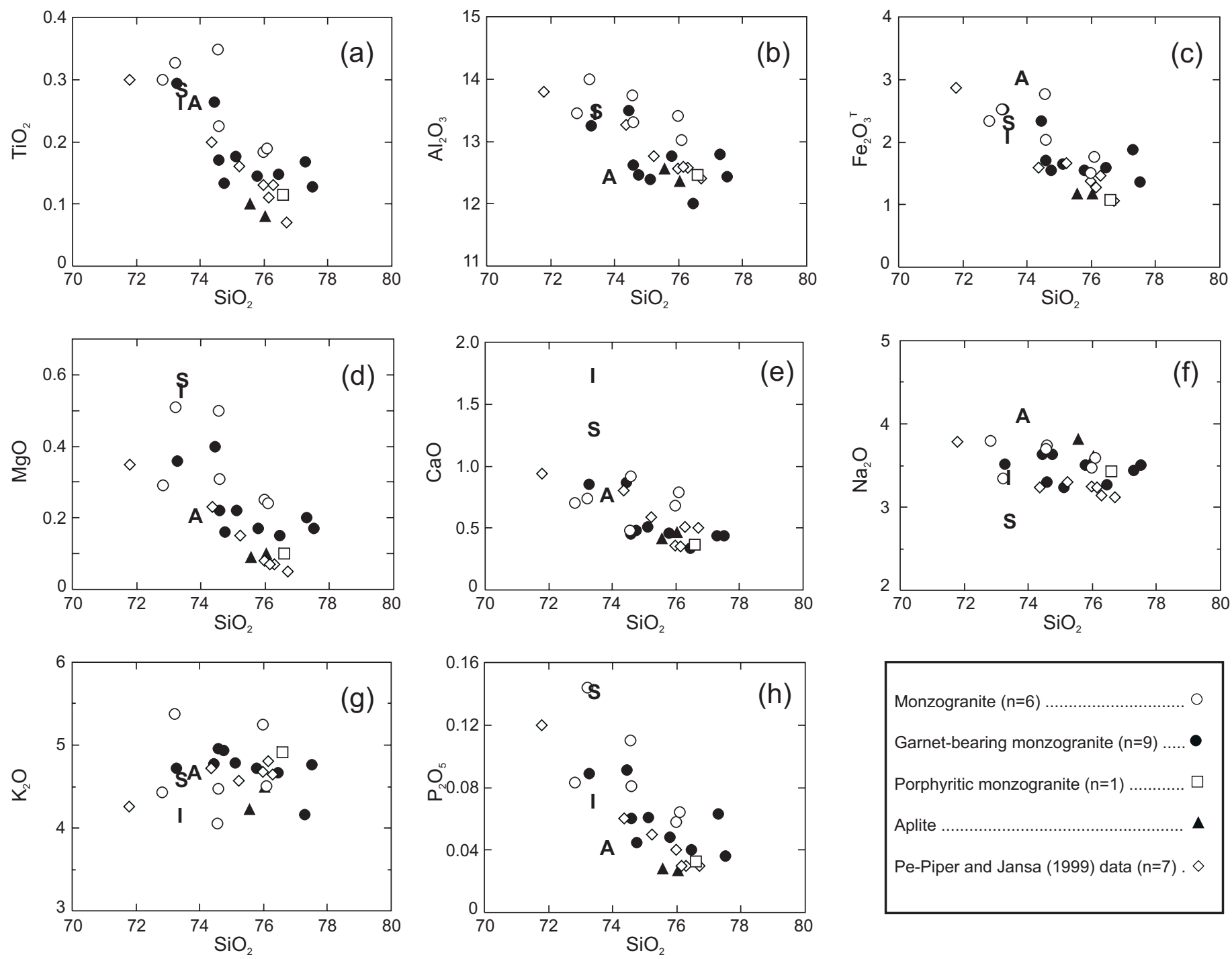

Fig. 6 Plots of major element oxides against $\mathrm{SiO}_{2}($ all in weight \%) to illustrate chemical variation in the Wedgeport pluton. Chemical data are from Table 2 and Pe-Piper and Jansa (1999). Letters I, S, and A are the compositions of the average A-, felsic I-, and felsic S-type granites from Whalen et al. (1987).

Table 4. New Sm-Nd isotopic data for sample 016-WO2-04A from the Wedgeport pluton

\begin{tabular}{ccccccccc}
\hline $\mathrm{Nd}$ & $\mathrm{Sm}$ & ${ }^{147} \mathrm{Sm}$ & $\frac{143}{14 d}$ & $2 \sigma$ & $\varepsilon_{\mathrm{Nd}(0)}$ & $\varepsilon_{\mathrm{Nd}(\mathrm{t})}$ & $\mathrm{T}_{(\mathrm{DM})}$ \\
\hline $\mathrm{ppm})$ & $(\mathrm{ppm})$ & ${ }^{144} \mathrm{Nd}$ & ${ }^{144} \mathrm{Nd}$ & & \\
\hline 26.52 & 5.964 & 0.1360 & 0.512602 & 0.000030 & -0.7 & 2.1 & $873 \mathrm{Ma}$ \\
\hline
\end{tabular}

Notes: Analyses by Alain Potrel, Memorial University of Newfoundland. Sm and Nd contents and Nd isotopic composition were analyzed using a multicollector Finnigan Mat 262 mass spectrometer in static mode. Nd isotopic ratio are normalized to ${ }^{146} \mathrm{Nd} /{ }^{144} \mathrm{Nd}=0.7219$. The reported values were adjusted to La Jolla $\mathrm{Nd}$ standard $\left({ }^{143} \mathrm{Nd} /{ }^{144} \mathrm{Nd}=0.511860\right)$. During the course of data acquisition replicates of the standard gave a mean value of ${ }^{143} \mathrm{Nd} /{ }^{144} \mathrm{Nd}=0.511886 \pm 26(2 \sigma, \mathrm{n}=18)$. The in-run precisions on $\mathrm{Nd}$ isotopic ratio are given at $95 \%$ confidence level. Error on $\mathrm{Nd}$ isotopic compositions are $<0.002 \%$ and errors on the ${ }^{147} \mathrm{Sm} /{ }^{144} \mathrm{Nd}$ ratio are estimated to be less than $0.1 \%$. The $\varepsilon_{\mathrm{Nd}}$ values are calculated using a ${ }^{147} \mathrm{Sm} /{ }^{144} \mathrm{Nd}=0.1967$ and ${ }^{143} \mathrm{Nd} /{ }^{144} \mathrm{Nd}=0.512638$ values for the present day chondrite uniform reservoir (CHUR). ${ }^{147} \mathrm{Sm}$ decay constant is $6.5410^{-12} \mathrm{y}^{-1}$ (Steiger and Jäger 1977). The depleted mantle model age, $\mathrm{T}_{(\mathrm{DM})}$, was calculated both with respect to depleted mantle with $\varepsilon_{\mathrm{Nd}(0)}$ value of +10 isolated from the CHUR since 4.55 Ga and following a linear evolution with respect to the De Paolo (1988) mantle model. 

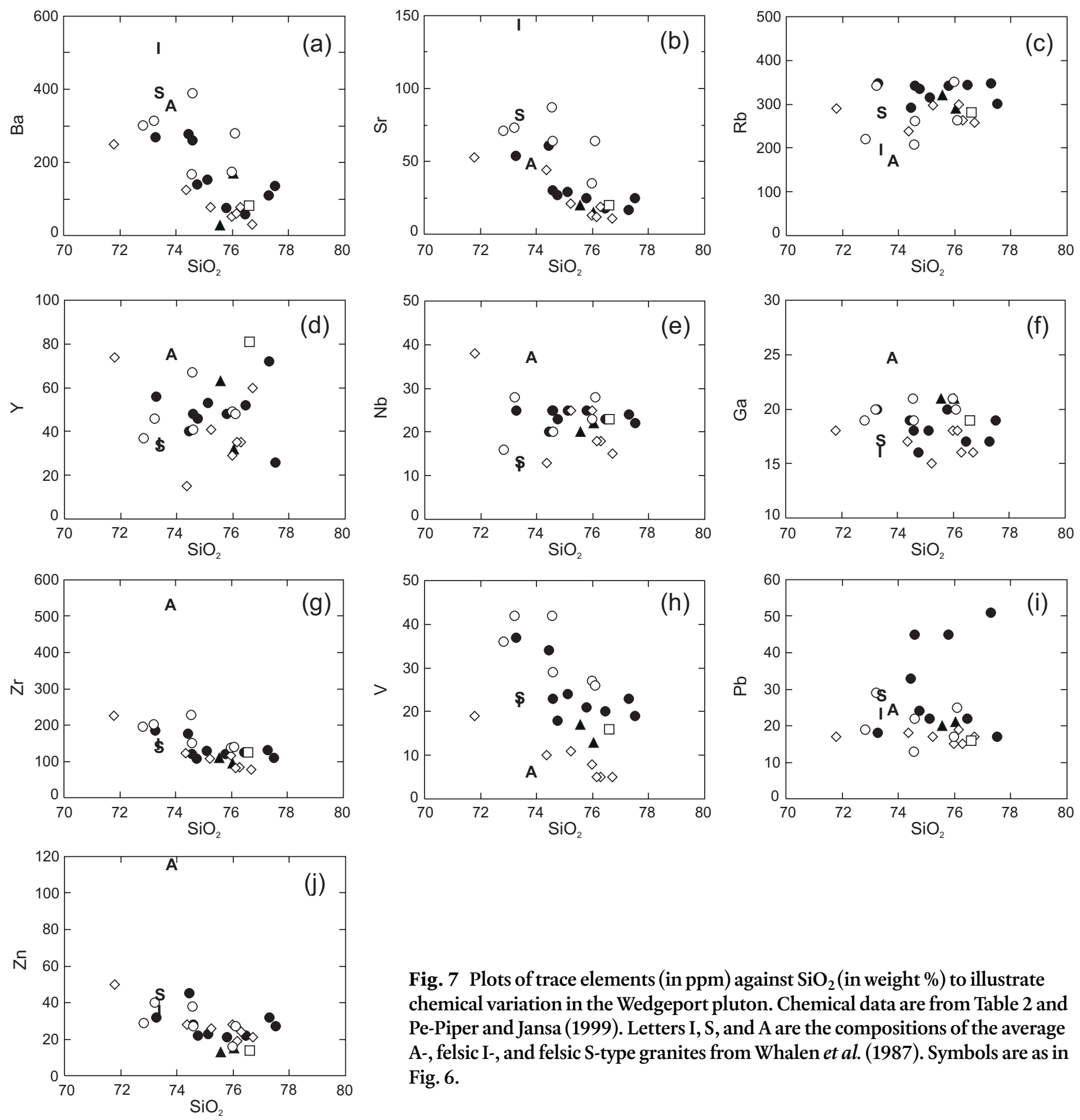

Fig. 7 Plots of trace elements (in ppm) against $\mathrm{SiO}_{2}$ (in weight \%) to illustrate chemical variation in the Wedgeport pluton. Chemical data are from Table 2 and Pe-Piper and Jansa (1999). Letters I, S, and A are the compositions of the average A-, felsic I-, and felsic S-type granites from Whalen et al. (1987). Symbols are as in Fig. 6. 
(a)

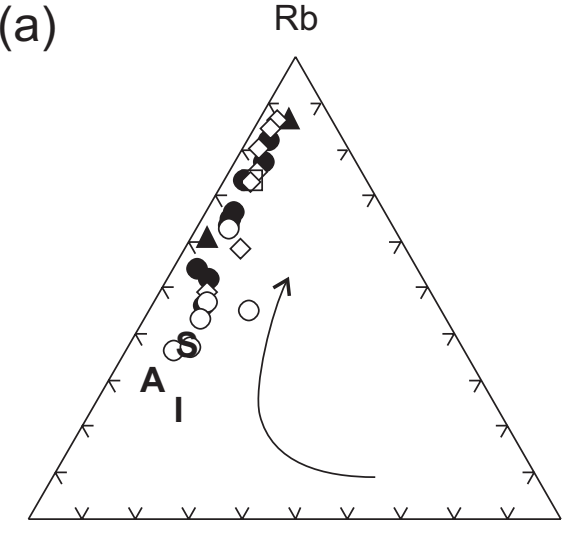

$\mathrm{Ba}$
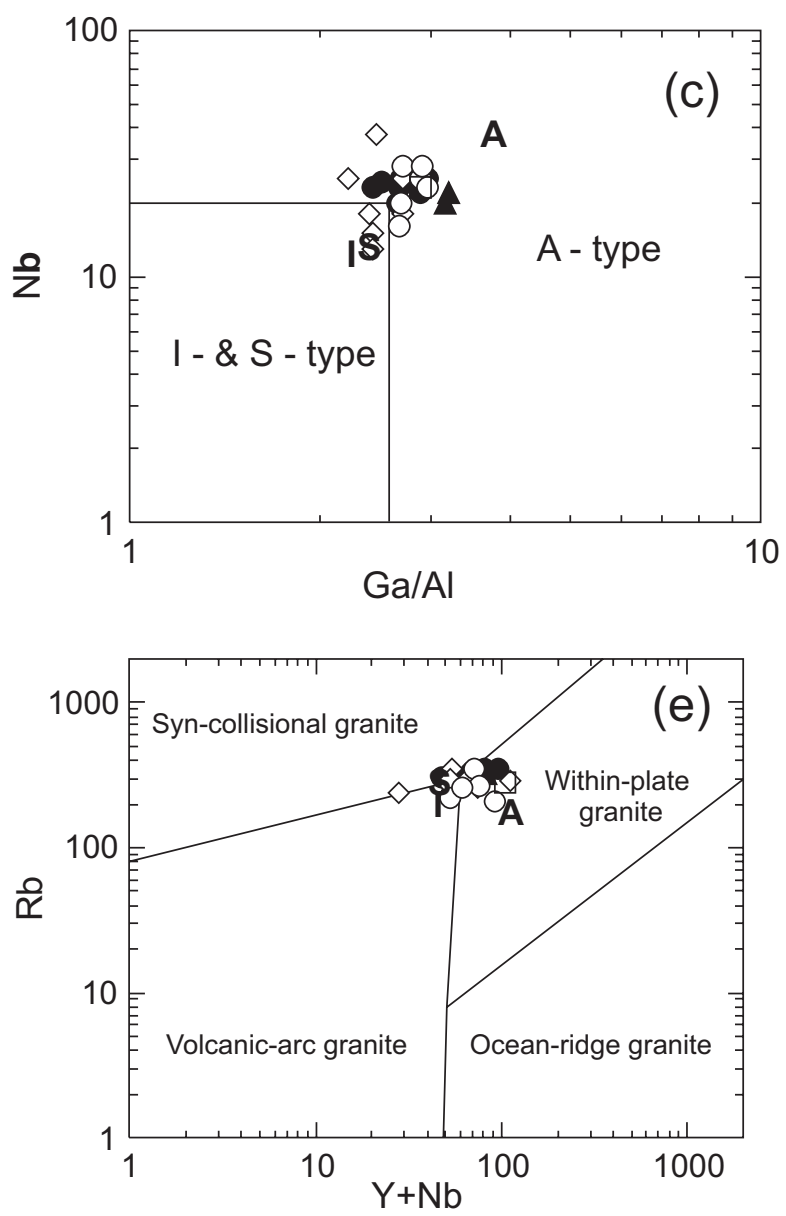
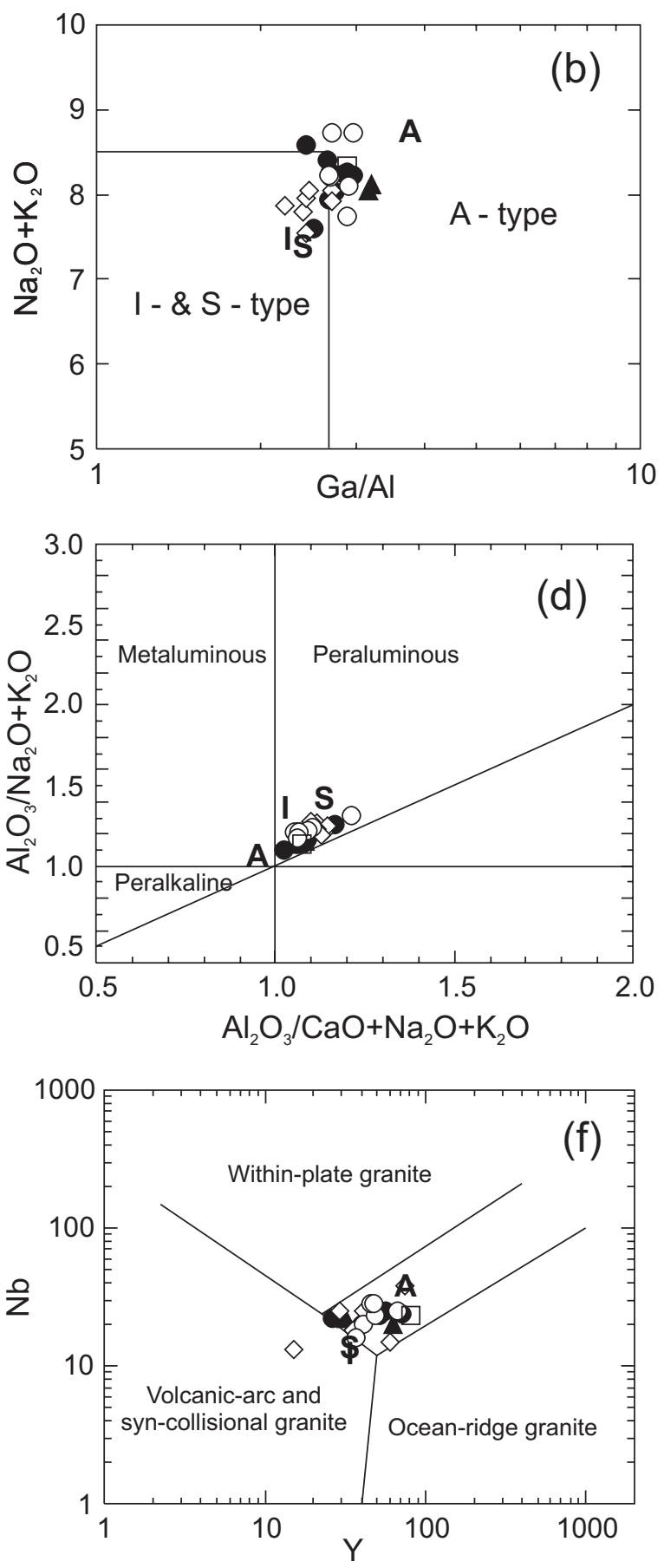

Fig. 8 Plots of (a) Ba-Rb-Sr, (b) $\mathrm{Na}_{2} \mathrm{O}+\mathrm{K}_{2} \mathrm{O}$ against $\mathrm{Ga} / \mathrm{Al}$, (c) $\mathrm{Nb}$ against $\mathrm{Ga} / \mathrm{Al}$, (d) $\mathrm{Al}_{2} \mathrm{O}_{3} /\left(\mathrm{Na}_{2} \mathrm{O}+\mathrm{K}_{2} \mathrm{O}\right.$ ) against $\mathrm{Al}_{2} \mathrm{O}_{3} /$ $\left(\mathrm{CaO}+\mathrm{Na}_{2} \mathrm{O}+\mathrm{K}_{2} \mathrm{O}\right),(\mathrm{e}) \mathrm{Rb}$ against $\mathrm{Y}+\mathrm{Nb}$, and (f) $\mathrm{Nb}$ against $\mathrm{Y}$. Arrow in (a) shows trend toward enriched granite after El Bouseily and El Sokkary (1975). Fields in (b) are from Maniar and Piccoli (1989), in (c) and (d) from Whalen et al. (1987), and in (e) and (f) from Pearce et al. (1984). Data sources and symbols are as in Fig. 6. 

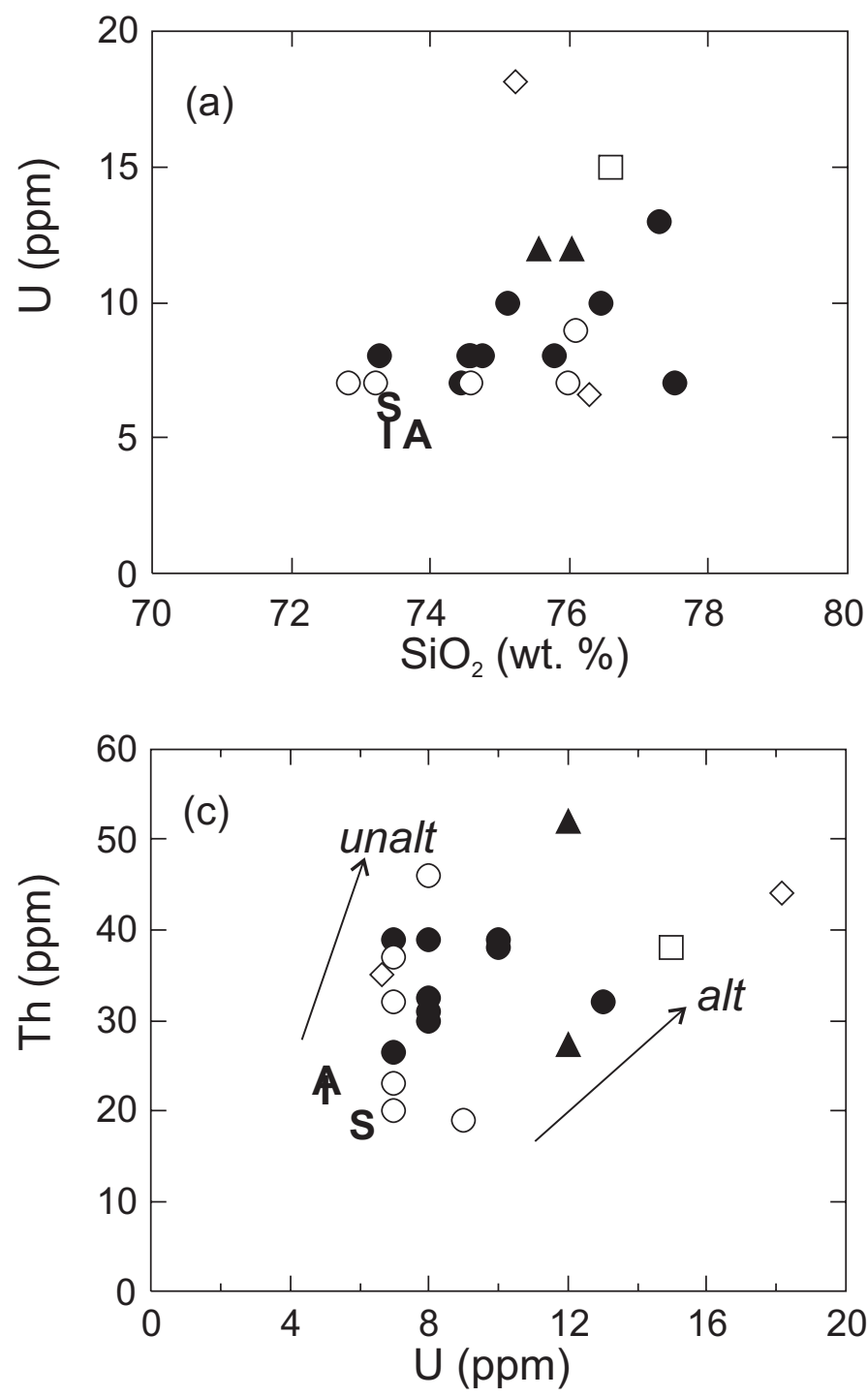

compared to the averages from Whalen et al. (1987). Whalen et al. (1987) used the $\mathrm{Ga} / \mathrm{Al}$ ratio as a distinguishing feature of these granite types, and plots of $\mathrm{Na}_{2} \mathrm{O}+\mathrm{K}_{2} \mathrm{O}$ and $\mathrm{Nb}$ against $\mathrm{Ga} / \mathrm{Al}$ suggest a composition intermediate between A-type and felsic I- and S-type granites (Fig. 8b, c). However, the presence of iron-rich biotite and abundant titanite and fluorite are more consistent with A-type character. A plot of $\mathrm{Al}_{2} \mathrm{O}_{3} / \mathrm{Na}_{2} \mathrm{O}+\mathrm{K}_{2} \mathrm{O}$ against $\mathrm{Al}_{2} \mathrm{O}_{3} / \mathrm{CaO}+\mathrm{Na}_{2} \mathrm{O}+\mathrm{K}_{2} \mathrm{O}$ shows that the Wedgeport pluton is peraluminous (Fig. 8d). Other peraluminous characteristics of the Wedgeport pluton include the presence of garnet in many samples.

The samples plot at the junction of the within-plate, syncollisional, and volcanic-arc granitoid fields on the $\mathrm{Rb}$ against $\mathrm{Y}+\mathrm{Nb}$ discrimination diagram (Fig. 8e) but more definitively in the A-type field on the Nb-Y diagram (Fig. 8f).

\section{Rare-Earth Element Data}

Rare-earth element (REE) data were obtained for 5 samples (four granite and one aplite) during the present study (Table

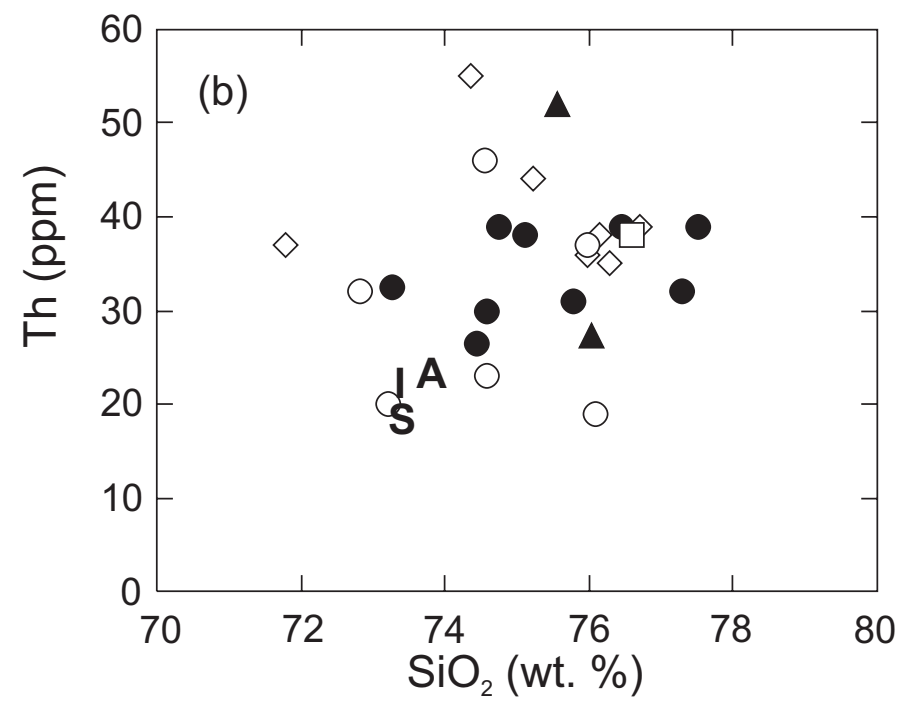

Fig. 9 Plots of (a) $\mathrm{U}$ and (b) Th against $\mathrm{SiO}_{2}$, and (c) Th against $U$ to illustrate chemical variation in the Wedgeport pluton. Data sources and symbols are as in Fig. 6. Trend arrows for unaltered (unalt) and altered (alt) samples in (c) are estimated from Chatterjee et al. (1985).

3), and an additional two samples are available from Pe-Piper and Jansa (1999). The patterns for all of the granite samples are similar, and show moderate enrichment in the light REE, a large negative Eu anomaly, and a flat heavy REE at 20 to 40 times chondritic values (Fig. 10). The aplite sample shows a strongly contrasting pattern, with no enrichment in the light REE and increasing enrichment in the heavy REE. No obvious mineralogical differences such as high garnet content are evident in the aplite to explain the REE pattern.

\section{Isotopic Data}

The Sm-Nd data for the dated sample 016-WO2-004A (Table 4) are similar to those reported for two samples by Pe-Piper and Jansa (1999). The $\varepsilon_{\mathrm{Nd}}$ value at $357 \mathrm{Ma}$ is 2.1, whereas the two samples from Pe-Piper and Jansa (1999) have values (at $357 \mathrm{Ma}$ ) of 2.1 and 3.1. These relatively high positive values contrast markedly with reported $\varepsilon_{\mathrm{Nd}}$ values for other granitic plutons in the Meguma terrane, which have negative values ranging from -1.4 to -5.2 at $372 \mathrm{Ma}$ (Clarke et al. 1988). 


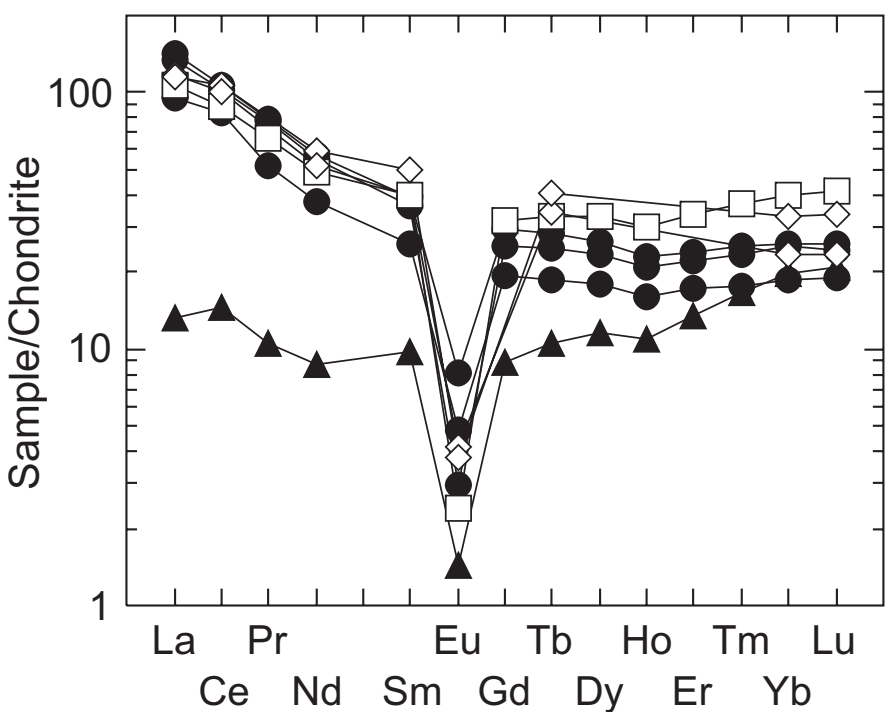

Fig. 10 Chondrite-normalized REE plot, using data from Table 3 and Pe-Piper and Jansa (1999). Chondrite-normalizing values are from Sun and McDonough (1989). Symbols are as in Fig. 6.

The positive values in the Wedgeport pluton samples suggest a relatively primitive source and allow for little contamination from the metasedimentary host rocks of the Meguma Group, which have very negative $\varepsilon_{\mathrm{Nd}}$ values of ca. -10 (Clarke et al. 1988). Instead, they are similar to values from minor mafic plutons of the Meguma terrane, for which mainly positive values have been reported (Tate and Clarke 1995). They are also similar to values reported by MacDonald et al. (2002) for ca. 440 Ma rhyolite in the White Rock Formation in the Yarmouth area $\left(\varepsilon_{\mathrm{Nd}}=1.37\right)$, although the ca. $440 \mathrm{Ma}$ Brenton pluton has a lower value $\left(\varepsilon_{\mathrm{Nd}}=-0.42\right)$.

\section{DISCUSSION AND CONCLUSIONS}

The revised age reported here for the Wedgeport pluton shows that it is 40 million years older than previously assumed, that is earliest Carboniferous (Okulitch 2002) as opposed to late Carboniferous. Hence the pluton cannot be associated with the late thermal events at ca. 320-315 Ma in the Meguma terrane, nor with the shear zones of late Carboniferous age, as suggested by previous workers (Dallmeyer and Keppie 1987; Keppie and Dallmeyer 1995; Culshaw and Reynolds 1997; see compilation in White 2003).

The $357 \pm 1 \mathrm{Ma}$ age is significantly younger than the ages from the South Mountain Batholith and its satellite plutons, Shelburne and Barrington Passage (Fig. 1), all of which have yielded ca. $372 \mathrm{Ma}$ ages. It is also much younger than the nearby Brenton Pluton (Fig. 1), which is Silurian (MacDonald et al. 2002). No other igneous activity of ca. $357 \mathrm{Ma}$ is known in the Meguma terrane, although abundant plutons of similar age occur north of the Cobequid - Chedabucto fault system in northern mainland Nova Scotia (Dunning et al. 2002).
However, the latter plutons differ from the Wedgeport pluton in that they are part of bimodal gabbro-granite suites with clear A-type features, and occur in association with voluminous bimodal volcanic rocks. Pe-Piper and Jansa (1999) compared offshore plutons with onshore plutons, including the Wedgeport pluton, and showed that none of the offshore plutons has petrochemical characteristics that match those of the Wedgeport pluton.

A possible link may exist between the Wedgeport pluton and mineralization in spodumene-bearing pegmatite bodies in the Brazil Lake area north of the Wedgeport pluton (Fig. 1). Pegmatite in this area occurs as elongate lenses in deformed metavolcanic and metasedimentary rocks of the Silurian White Rock Formation. Although U-Pb dating of tantalite indicated that the pegmatite crystallized at $378 \pm 1 \mathrm{Ma}$, molybdenite from an adjacent quartz vein yielded a Re/Os age of $354 \pm 3$ $\mathrm{Ma}$ (Kontak et al. 2003). This result indicates that mineralization in the Brazil Lake area is of similar age to the crystallization age of the Wedgeport pluton. Although it does not prove a genetic link between the two areas, the similar ages, younger than ages of other plutons known in the Meguma terrane, may be significant.

In addition to its anomalous age, the Wedgeport pluton also has anomalous petrochemical characteristics. It cannot be classified as any of the commonly accepted granite end-members, and its tectonic setting is not evident from its petrochemical features using commonly applied discrimination diagrams. However, a within-plate tectonic setting is most likely, both from the petrochemical features and the inferred tectonic situation of the Meguma terrane in the earliest Carboniferous. At that time, the Meguma terrane was being uplifted and unroofed, and shedding sedimentary material into Carboniferous basins. The northwestern part of the South Mountain Batholith was exposed by 357 Ma when the Wedgeport pluton was being emplaced, as conglomerate in the overlying units contains debris derived from the batholith. However, it is clear that the area around the Wedgeport pluton was still buried. The depth of emplacement of the Wedgeport pluton was likely epizonal, based on the presence of a welldeveloped contact metamorphic aureole containing cordierite and andalusite, and localized development of porphyritic, granophyric, and inequigranular textures near the margins.

The Wedgeport pluton appears to be a unique intrusion in the Meguma terrane, both in terms of its age and its composition, and remains an enigma in terms of its origin.

\section{ACKNOWLEDGEMENTS}

This project was funded mainly by the Nova Scotia Department of Natural Resources through the Southwest Nova Mapping Project. Barr's contributions were funded by a Discovery Grant from the Natural Sciences and Engineering Research Council of Canada. We thank Georgia Pe-Piper for providing locations for samples reported by Pe-Piper and Jansa 
(1999). Ken Currie and Linda Ham provided helpful reviews which improved the manuscript.

\section{REFERENCES}

Cant, J.W., Fisher, D.F., Wilson, B.H., Dickie, G.B., \& SARKAR, P.K. 1978. Report of exploration in Yarmouth County, Nova Scotia, (NTS 20/O and 20/P), May 1976 to April 1978; Shell Canada Resources Limited; Nova Scotia Department of Natural Resources Assessment Report A.R. 433144.

Chatterjee, A.K., \& Keppie, J.D. 1981. Polymetallic mineralization in the endo- and exo-contact of the Wedgeport Pluton, Yarmouth County. In Nova Scotia Department of Mines and Energy Report 81-1, pp. 43-46.

Chatterjee, A.K., Strong, D.F., Clarke, D.B., \& Keppie, J.D. 1985. Geology and geochemistry of the Carboniferous Wedgeport Pluton hosting Sn-W mineralization. In Guide to plutons and Mineral Deposits of Southwestern Nova Scotia. Edited by A.K. Chatterjee \& D.B. Clarke. Nova Scotia Department of Mines and Energy, Preprint of Paper 85-3, pp. 202-216.

Clarke, D.B., Halliday, A.N., \& Hamilton, P.J. 1988. Neodymium and strontium isotopic constraints on the origin of peraluminous granitoids of the South Mountain Batholith, Nova Scotia, Canada. Chemical Geology (Isotope Geoscience Section), 73, pp. 15-24.

Clarke, D.B., MacDonald, M.A., \& Tate, M.C. 1997. Late Devonian mafic-felsic magmatism in the Meguma Zone, Nova Scotia. In The Nature of Magmatism in the Appalachian Orogen. Edited by A.K. Sinha, J.B. Whalen, \& J.P. Hogan. Geological Society of America Memoir 191, pp. 107-127.

Cormier, R.F., Keppie, J.D., \& Odom, A.L. 1988. U-Pb and $\mathrm{Rb}$-Sr geochronology of the Wedgeport granitoid pluton, southwestern Nova Scotia. Canadian Journal of Earth Sciences, 25, pp. 255-261.

Cullen,J.D. 1983. Metamorphic petrology and geochemistry of the Goldenville Formation metasediments, Yarmouth, Nova Scotia. M. Sc. thesis, Dalhousie University, Halifax, Nova Scotia, $241 \mathrm{p}$.

Culshaw, N., \& Liesa, M. 1997. Alleghanian reactivation of the Acadian fold belt, Meguma Zone, southwest Nova Scotia. Canadian Journal of Earth Sciences, 34, pp. 833-847.

Culshaw, N., \& Reynolds, P. 1997. ${ }^{40} \mathrm{Ar} /{ }^{39} \mathrm{Ar}$ age of shear zones in the southwest Meguma Zone between Yarmouth and Meteghan, Nova Scotia. Canadian Journal of Earth Sciences, 34, pp. 848-853.

Dallmeyer, R.D., \& Keppie, J.D. 1987. Polyphase late Paleozoic tectonothermal evolution of the southwestern Meguma terrane, Nova Scotia: evidence from ${ }^{40} \mathrm{Ar} /{ }^{39} \mathrm{Ar}$ mineral ages. Canadian Journal of Earth Sciences, 24, pp. 1242-1254.

Dallmeyer, R.D., \& Keppie, J.D. 1988. Superposed Late Paleozoic thermal events in the southwestern Meguma terrane, Nova Scotia. Maritime Sediments and Atlantic Geology, v. 24, pp. 157-169.

DAvis, D.W. 1982. Optimum linear regression and error estimation applied to U-Pb data. Canadian Journal of Earth Sciences, 19, pp. 2141-2149.

DePaolo, D.J. 1988. Neodymium isotope geochemistry. New York, Springer-Verlag, $187 \mathrm{p}$.

Dunning, G.R., BARr, S.M., Giles, P.S., McGregor, D.C., Pe-Piper, G., \& Piper, D.J.W. 2002. Chronology of Devonian to early Carboniferous rifting and igneous activity in southern Magdalen Basin based on U-Pb (zircon) dating. Canadian Journal of Earth Sciences, 39, pp. 1219-1237.

El Bouseily, A.M., \& El SokKary, A.A. 1975. The relation between $\mathrm{Rb}, \mathrm{Ba}$, and $\mathrm{Sr}$ in granitic rocks. Chemical Geology, 16, pp. 207-219.

Hicks, R.J., Jamieson, R.A., \& Reynolds, P.H. 1999. Detrital and metamorphic ${ }^{40} \mathrm{Ar} /{ }^{39} \mathrm{Ar}$ ages from muscovite and whole-rock samples, Meguma Supergroup, southern Nova Scotia. Canadian Journal of Earth Sciences, 36, pp. 23-32.

Jaffey, A.H., Flynn, K.F., Glendenin, L.E., Bentley, W.C., \& EssLING, A.M. 1971. Precision measurement of half-lives and specific activities of ${ }^{235} U$ and ${ }^{238} U$. Physical Review, 4, pp. 1889-1906.

KePPIE, J.D. (Compiler) 2000. Geological map of the province of Nova Scotia. Nova Scotia Department of Natural Resources and Energy, Map ME2000-1. Scale 1:500 000.

Keppie, J.D., \& Dallmeyer, R.D. 1995. Late Paleozoic collision, delamination, short-lived magmatism, and rapid denudation in the Meguma Terrane (Nova Scotia, Canada): constraints from ${ }^{40} \mathrm{Ar} /{ }^{39} \mathrm{Ar}$ isotopic data. Canadian Journal of Earth Sciences, 32, pp. 644-659.

KING, M.S. 1997a. Meguma Terrane, enhanced (second vertical derivative) aeromagnetic digital data for NTS 20O/16, Yarmouth County, Nova Scotia. Nova Scotia Department of Natural Resources, Minerals and Energy Branch, Open File Map 97-030.

KING, M.S. 1997b. Meguma Terrane, enhanced (second vertical derivative) aeromagnetic digital data for NTS 20P/13, Yarmouth and Shelburne Counties, Nova Scotia. Nova Scotia Department of Natural Resources, Minerals and Energy Branch, Open File Map 97-031.

Kontak, D.J., Groat, L., \& Barnes, E. 2003. Comparison of the Brazil Lake, Nova Scotia, and Little Nahanni, N.W.T., LCT pegmatite suites. In Mining Matters for Nova Scotia 2003, Opportunities for Economic Development; Nova Scotia Department of Natural Resources, Minerals and Energy Branch, Report ME 2003-2, p. 8.

Krogh, T.E. 1973. A low contamination method for hydrothermal decomposition of zircon and extraction of $U$ and $\mathrm{Pb}$ for isotopic age determinations. Geochimica et Cosmochimica Acta, 37, pp. 485-494.

KROGH, T.E. 1982. Improved accuracy of U-Pb ages by the creation of more concordant systems using an air abrasion technique. Geochimica et Cosmochimica Acta, 46, pp. 637-649. 
Longerich, H., JenNer, G.A., Fryer, B.J., \& Jackson, S.E. 1990. Inductively coupled plasma- mass spectrometric analysis of geochemical samples. A critical evaluation on case studies. Chemical Geology, 83, pp. 105-118.

MacDonald, L.A., Barr, S.M., White, C.E., \& Ketchum, J.W. F. 2002. Petrology, age, and tectonic setting of the White Rock Formation, Meguma terrane, Nova Scotia: evidence for Silurian continental rifting. Canadian Journal of Earth Sciences, 39, pp. 259-277.

MacLean, N. 2003. Petrology \& tectonic setting of the Wedgeport Pluton, southwestern Nova Scotia. Unpublished BSc Honours thesis, Acadia University, Wolfville, Nova Scotia, $94 \mathrm{p}$.

Maniar, P.D., \& Piccoli, P.M. 1989. Tectonic discrimination of granitoids. Geological Society of America Bulletin, 101, pp. 635-643.

Muecke, G.K, Elias, P. \& Reynolds, P.H. 1988. Hercynian/ Alleghanian overprinting of an Acadian Terrane: ${ }^{40} \mathrm{Ar} /{ }^{39} \mathrm{Ar}$ studies in the Meguma Zone, Nova Scotia. Chemical Geology, 73, pp. 153-167.

Окицттсн, A.V. 2002. Geological time chart 2002. Geological Survey of Canada Open File 3040. National Earth Science Series - Geological Atlas. Revision.

Pe-Piper, G., \& Jansa, L.F. 1999. Pre-Mesozoic basement rocks offshore Nova Scotia, Canada: New constraints on the accretion history of the Meguma terrane. Geological Society of America Bulletin, 111, pp. 1773-1791.

Pe-Piper, G., \& Reynolds, P.H. 2000. Early Mesozoic alkaline mafic dykes, southwestern Nova Scotia, Canada, and their bearing on Triassic-Jurassic magmatism. The Canadian Mineralogist, 38, pp. 217-232.

Pearce, J.A., Harris, N.W.B., \& Tindle, A.G. 1984. Trace element determination diagrams for the tectonic interpretation of granitic rocks. Journal of Petrology, 25, pp. 956-983.

Reynolds, P.H., Zentilli, M., \& Muecke, G.K. 1981. K-Ar and ${ }^{40} \mathrm{Ar} /{ }^{39} \mathrm{Ar}$ geochronology of granitoid rocks from southern Nova Scotia: Its bearing on the geological evolution of the Meguma Zone of the Appalachians. Canadian Journal of Earth Sciences, 18, pp. 386-394.

Reynolds, P.H., Elias, P., Muecke, G.K., \& Grist, A.M. 1987. Thermal history of the southwestern Meguma Group, Nova Scotia, from ${ }^{40} \mathrm{Ar} /{ }^{39} \mathrm{Ar}$ and fission track dating study of intrusive rocks; Canadian Journal of Earth Sciences, 24, pp. 1952-1965.
Steiger, R.H., \& JäGER, H. 1977. Subcommission on geochronology: convention on the use of decay constants in geo- and cosmochronology. Earth and Planetary Science Letters, 36, pp. 359-362.

Streckeisen, A.L. 1976. To each plutonic rock its proper name. Earth Science Reviews, 12, pp. 1-33.

Sun, S.S., \& McDonough, W.F. 1989. Chemical and isotopic systematics of oceanic basalts: implications for mantle composition and processes. In Magmatism in the ocean basins. Edited by A.D. Saunders \& M.J. Norry. Geological Society, London, pp. 313-345.

Tate, M.C., \& Clarke, D.B. 1995. Petrogenesis and regional tectonic significance of Late Devonian mafic intrusions in the Meguma Zone, Nova Scotia. Canadian Journal of Earth Sciences, 32, pp. 1883-1898.

TAYLOR, F.C. 1967. Reconnaissance geology of Shelburne maparea, Queens, Shelburne, and Yarmouth counties, Nova Scotia. Geological Survey of Canada Memoir 349, 83 p.

Whalen, J.B., Currie, K.L., \& Chappell, B.W. 1987. A-type granites: geochemical characteristics, discrimination and petrogenesis. Contributions to Mineralogy and Petrology, 95, pp. 407-419.

White, C.E. 2003. Preliminary bedrock geology of the area between Chebogue Point, Yarmouth County, and Cape Sable Island, Shelburne County, southwestern Nova Scotia. In Minerals and Energy Branch, Report of Activities 2002; Nova Scotia Department of Natural Resources, Minerals and Energy Branch, Report 2003-1, pp. 127-145.

White, C. E., \& KInG, M. S. 2002. Preliminary Bedrock Geology of the Tusket Map Area (NTS 20P/13), southwestern Nova Scotia. In Minerals and Energy Branch, Report of Activities 2001; Nova Scotia Department of Natural Resources, Minerals and Energy Branch, Report ME 20021, pp. 141-158.

White, C.E., Horne, R.J., Teniere, P.J., Jodrey, M.J., \& KING, M.S. 2001. Geology of the Metaghan River - Yarmouth area: a progress report on the Southwest Nova Scotia Mapping Project. In Nova Scotia Department of Natural Resources, Minerals and Energy Branch, Report of Activities 2000. Edited by D.R. MacDonald \& K.A. Mills. Report 2001-1, pp. 95-111.

Wolfson, I. K. 1983. A study of the tin mineralization and lithogeochemistry in the area of the Wedgeport Pluton, southwestern Nova Scotia. M. Sc. thesis, Dalhousie University, Halifax, Nova Scotia, 396 p. 
